Ann. Génét. Sél. anim., 1973, 5 (3), 415-4I6.

NOTE

\title{
AN INTER-STRAIN OBSERVATION ON THE RELATIONSHIP BETWEEN PERFORMANCE AND ITS HERITABILITY IN THE FOWL ( $\left.{ }^{1}\right)$
}

\author{
X. COLONNA-CESARI and J. P. BOYER \\ Station de Recherches avicoles, \\ Centre de Recherches de Tours, I. N.R. A., \\ Nouzilly, B. P. 1, 37380 Monnaie
}

\section{SUMMARY}

In a comparison between strains, for three traits, the rank correlation between mean value and heritability was estimated. This correlation was negative for 8-week weight and laying intensity, positive for sexual precicity.

In 1960-6I, we have estimated the heritability of some traits in several strains used by breeders of the Syndicat national des aviculteurs Agréés. Notwithstanding the very large differences between the environmental conditions supplied to the diverses strains (meat and egg-laying types) it is interesting to consider the general results and to compare the mean performances with the heritabilities estimated from hierarchical analysis of variance.

Thus, we draw,

I. For the 8 whs live weight (grams) :

$\begin{array}{crrrrrrr}\text { strain } & V 11 & C 11 & A 77 & F 11 & W A & W B & W C \\ \text { mean } & 998 & 945 & 866 & 806 & 769 & 694 & 643 \\ h^{2} \text { p. I00 } & 8 & 2 \text { I } & 24 & 43 & 30 & 62 & 75\end{array}$

The ranking coefficient of correlation is $p=0,98$.

The whole range of $h^{2}$ is present. This can be an indication that in the case of the live weight, the main part of the genetic variance is an additive one.

( $\left.{ }^{1}\right)$ Cet article a été présenté à la réunion du groupe de travail no 3 (sélection et testage) de la Fédération des Branches européennes de la W. P. S. A., Nouzilly-Ploufragan, 6-ro septembre I97I. 
2. For the age at first egg (days) :

\begin{tabular}{crrrrrrrrr} 
strain & \multicolumn{1}{c}{$B C$} & $C 11$ & $T 11$ & $W A$ & $F 11$ & $W B$ & $W C$ & $L$ & $A 77$ \\
mean & 154 & 159 & I62 & 167 & 169 & I 71 & I 77 & I 81 & 210 \\
$h^{2}$ p. 100 & 67 & 52 & 40 & 57 & 27 & I0 & 34 & 30 & 16
\end{tabular}

Here, better is the precocity, higher is the heritability. This may be suggestion to think that precocity is governed by recessive genes. In terms of age at first egg, the ranking coefficient of correlation is $p=0,77$.

3. For laying intensity (p. Ioo) :

$\begin{array}{lrrrrrrrrrrr}\text { strain } & S 11 & T 11 & L & C 11 & A 77 & B C & V 11 & F 11 & W A & W B & W B \\ \text { mean } & 46 & 49 & 50 & 52 & 63 & 65 & 65 & 65 & 72 & 75 & 76 \\ h^{2} & 17 & 26 & 37 & 18 & 16 & 21 & 30 & 10 & 26 & 40 & 20\end{array}$

The low range of heritability (I0-40 p. IOo) can manifest the importance of non-additive effects. The ranking coefficient of correlation is $p=0,44$. So there seems, in all cases, to be a negative relationship between performance and its heritability. This can be viewed as an indication that selection, partly at least, improves the performances at the cost of erroding the genetic variability. The case of WC strain intensity is noticeable because the highness of both average value and heritability. This fact suggests to estimate the two parameters before to begin a selection program. All in all, these results encounter somewhat a paradox with the frequently observed fact that better is the management, better is the performance and better the heritability So, it is proposed that a clear discrimination has to be made between "improvement by selection", which erodes the genetic variance, and "improvement by environment ", which, on the contrary, realizes a hidden variation. The play of the two factors does permit to hope an environment resource to be found, each time the heritability becomes too low before calling for a migration of new strains.

Reçu pour publication en mars 1973.

\author{
RÉSUMÉ \\ OBSERVATION ENTRE SOUCHES DE LA RELATION ENTRE NIVEAU \\ DE PERFORMANCE ET HÉRITABII,ITÉ CHEZ LA POULE
}

Dans une comparaison entre lignées, pour 3 caractères, la corrélation de rang entre la valeur moyenne de la performance et son héritabilité a été estimée. Cette corrélation est négative en ce qui concerne le poids à 8 semaines et l'intensité de ponte, positive pour la précocité sexuelle. 